\title{
Analisis Produktivitas Maksimum Penggunaan Lahan dengan Metode Highest and Best Use (HBU) pada Lahan Kosong di Kawasan Perumahan Royal Residence, Surabaya
}

\author{
Christsanto Wijaya dan Christiono Utomo \\ Jurusan Teknik Sipil, Fakultas Teknik Sipil dan Perencanaan, Institut Teknologi Sepuluh Nopember \\ Jl. Arief Rahman Hakim, Surabaya 60111 \\ E-mail: christiono@ce.its.ac.id
}

\begin{abstract}
Abstrak - Royal Residence merupakan salah satu komplek perumahan elit di daerah Surabaya Barat. Salah satu lahan dengan luas $9523,5 \mathrm{~m}^{2}$ di perumahan Royal Residence memiliki rencana awal untuk pengembangan perumahan. Namun, seiring dengan nilai lahan yang terus meningkat, perumahan belum tentu masih menjadi pilihan yang terbaik. Karena tingginya nilai lahan dan berada di depan rencana area komersial, lahan tersebut sangat cocok untuk dikembangkan menjadi apartemen dan juga properti komersial. Analisis Highest and Best Use (HBU) digunakan untuk menentukan penggunaan lahan untuk lahan kosong di kawasan perumahan Royal Residence ini. HBU adalah analisis produktivitas maksimum penggunaan lahan yang akan menentukan penggunaan tertinggi dan terbaik suatu lahan. Analisis HBU memiliki 4 kriteria yaitu aspek legal, aspek fisik, aspek finansial, dan memberikan produktivitas yang maksimum. Hasil penelitian ini didapatkan bahwa alternatif apartemen merupakan alternatif penggunaan tertinggi dan terbaik yang akan menghasilkan kenaikan nilai tanah sebesar Rp. $11.707 .798 / \mathrm{m}^{2}$ dengan produktivitas sebesar $113 \%$.
\end{abstract}

Kata kunci : HBU, Lahan, Prorperti Residensial, Properti Komersial

\section{I.PENDAHULUAN}

$\mathrm{P}$ ERTUMBUHAN properti baik untuk tempat tinggal, properti, maupun penggunaan lain yang semakin hari semakin tinggi. Hal ini mengakibatkan rencana pengembangan terhadap suatu lahan dapat berubah seiring dengan perubahan sekitarnya. Oleh karena itu, dibutuhkan sebuah analisis untuk menentukan peruntukan suatu lahan sehingga dapat menghasilkan alternatif properti dengan penggunaan tertinggi dan terbaik

Salah satu analisis penilaian tersebut adalah dengan metode Highest and Best Use (HBU). HBU adalah analisis terhadap kegunaan terbaik dan tertinggi dari suatu bidang tanah lahan kosong, lahan dalam pengembangan, ataupun lahan yang dianggap kosong [1]. Analisis HBU ini merupakan salah satu cara penilaian lahan yang sangat berguna dalam mempertimbangkan peruntukan lahan yang sesuai dan memiliki nilai tertinggi.

Penelitian akan dilakukan pada lahan kosong yang berada di kawasan Perumahan Royal Residence, di jalan Royal Residence B007 02-10, kelurahan Sumur Welut, kecamatan Lakarsantri, Surabaya. Lahan ini merupakan lahan dengan rencana awal untuk pengembangan properti perumahan. Namun seiring perkembangan wilayah sekitar, nilai lahan terus meningkat mengakibatkan alternatif pengembangan perumahan belum tentu menjadi pilihan terbaiknya. selain itu, lokasi lahan yang berada di seberang daerah CBD menjadikan lahan ini perpoteni untuk menjadi properti komersial. Oleh karena itu, perlu dilakukan analisis HBU untuk menentukan penggunaan tertinggi dan terbaik lahan tersebut.

\section{II.PENELITIAN TERDAHULU}

Rasyid dan Utomo (2013) [2], pada jurnal yang berjudul "Analisis Highest and Best Use (HBU) pada Lahan Bekas SPBU Biliton Surabaya", dengan menggunakan empat kriteria pokok, yaitu aspek fisik, aspek legal, aspek finansial, dan produktivitas maksimum. Hasil yang diperoleh dalam penelitian ini adalah peruntukan pertokoan yang produktivitas maksimum dengan nilai lahan sebesar $\mathrm{Rp}$ $16.457 .465 / \mathrm{m}^{2}$ dan memiliki produktivitas maksimum sebesar $65 \%$.

Penelitian oleh Akmaluddin dan Utomo (2012) [3], pada jurnal berjudul "Analisis Highest and Best Use (HBU) pada Lahan J1. Gubeng Raya No. 54 Surabaya”, yang berpotensi dikembangkan menjadi properti komersial antara lain hotel, apartemen, perkantoran dan pertokoan. Hasil dari analisis HBU didapatkan alternatif properti terbaik untuk lahan tersebut adalah properti komersial hotel dengan nilai lahan Rp. 67.069.980,31// $\mathrm{m}^{2}$.

Indrakusuma dan Utomo (2014) [4], menganalisis lahan kosong di Jalan Nias Surabaya seluas $2218 \mathrm{~m}^{2}$ dengan metode Highest and Best Use. Alternatif properti komersial yang digunakan yaitu apartemen, hotel, perkantoran dan pertokoan. Dari penelitian ini didapatkan apartemen menghasilkan nilai lahan tertinggi yaitu sebesar Rp. $39.540 .353 / \mathrm{m}^{2}$ dengan prosentase kenaikan $452 \%$.

Mubayyinah dan Utomo (2012) [5], menganalisis lahan "X" yang berlokasi di Jalan Raya Dr.Sutomo no.79-81 mempunyai luas $820 \mathrm{~m}^{2}$. Alternatif properti komersial yang digunakan yaitu apartemen, hotel, perkantoran dan pertokoan. Kesimpulan dari penelitian ini didapat alternatif hotel sebagai penggunaan lahan terbaik yang memiliki nilai lahan tertinggi yaitu sebesar Rp $13.148 .307 / \mathrm{m}^{2}$.

Anggarawati dan Utomo [6], menganalisis lahan kawasan komersial Perumahan Citra Raya Surabaya. Alternatif properti komersial yang digunakan adalah kantor, hotel dan kantor dengan ruang serbaguna. Kesimpulan dari penelitian ini didapatkan alternatif kantor sebagai penggunaan lahan tertinggi dan terbaik dengan nilai lahan sebesar Rp 27.984.580,59/ $\mathrm{m}^{2}$ dengan peningkatan prosentase produktivitas sebesar $74,9 \%$.

Faradiany dan Utomo[7], menganalisis lahan kosong di Jemur Gayungan II Surabaya. Alternatif properti komersial yang digunakan berupa apartemen, hotel dan perkantoran. Kesimpulan dari penelitian ini didapatkan alternatif hotel sebagai penggunaan lahan terbaik yang memiliki nilai lahan 
tertinggi yaitu sebesar Rp $9.772 .718 / \mathrm{m}^{2}$ dengan prodiktivitas meningkat sebesar $486 \%$.

Utami dan Utomo [8], menganalisis lahan kosong di kawasan wisata Ubud. Alternatif properti komersial yang digunakan menggunakan 3 alternatif mix used villa dan spa center, dimana alternatif tersebut dijadikan satu properti komersial dengan prosentase penggunaan yang telah ditentukan. Hasil yang didapatkan adalah penggunaan alternatif 1 mix used antara villa $60 \%$ dan spa center $40 \%$ dengan produktivitas sebesar $829 \%$ dan nilai lahan yang didapatkan adalah Rp 10.263.207/m².

Aziz dan Utomo [9], menganalisis lahan Gedung Serbaguna Purnama di Jl. R.A. Kartini Bangkalan. Alternatif properti komersial yang digunakan berupa supermarket, hotel, dan kolam renang. Hasil yang diperoleh yaitu hotel merupakan alternatif penggunaan tertinggi dengan nilai lahan sebesar $\mathrm{Rp} 4.086 .635 / \mathrm{m}^{2}$ dengan produktifitas maksimum sebesar $253 \%$.

\section{METODOLOGI}

Penelitian ini menggunakan konsep Highest and Best Use (HBU) untuk menganalisis penggunaan lahan kosong di kawasan perumahan Royal Residence yang dapat menghasilkan jenis properti tertinggi dan terbaik dengan berdasarkan aspek legal, aspek fisik, aspek finansial, dan produktifitas maksimum.

Beberapa rincian pengelompokan indikator dan jenis data yang dibutuhkan dalam penelitian disajikan dalam Tabel 1.

Tabel 1.

Variabel Penelitian

\begin{tabular}{|c|c|}
\hline Variabel & Indikator \\
\hline \multirow{7}{*}{ Aspek Legal } & 1. Zoning \\
\hline & 2. Building Code \\
\hline & a. Garis Sempadan Bangunan \\
\hline & b. Koefisien Dasar Bangunan \\
\hline & c. Koefisien Lantai Bangunan \\
\hline & d. Koefisien Dasar Hijau \\
\hline & e. Ketinggian Bangunan \\
\hline \multirow[t]{2}{*}{ Penentuan Alternatif } & Alternatif Awal \\
\hline & 1. Ukuran dan Bentuk Lahan \\
\hline \multirow{5}{*}{ Aspek Fisik } & 2. Utilitas \\
\hline & 3. Aksesibilitas \\
\hline & 4. Desain Alternatif \\
\hline & 1. Biaya Investasi \\
\hline & 2. Pendapatan \\
\hline \multirow[t]{3}{*}{ Aspek Finansial } & 3. Pengeluaran \\
\hline & 4. Aliran Kas \\
\hline & 5. Net Present Value \\
\hline Produktivitas Maksimum & Nilai Lahan Tertinggi \\
\hline
\end{tabular}

\section{Pendahuluan}

Analisa mendalam untuk mendapatkan alternatif penggunaan lahan tertinggi dan terbaik perlu dilakukan sebagai dasar pengembangan lahan Akan dilakukan analisa $H B U$ pada sebuah lahan di kawasan perumahan Royal Residence, Surabaya.
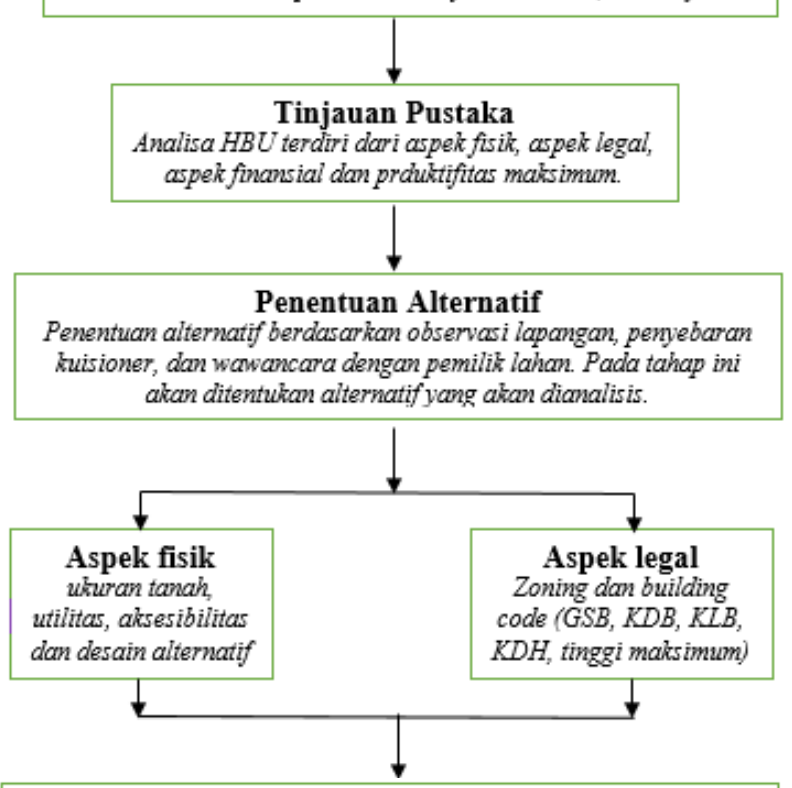

Aspek finansial

Aspek finansial akan meninjau kelayakan alternatif properti dari segi finansial. Pada tahap ini akan ditinjau biaya investasi, pendapatan pengeluaran dan aliran kas untuk setiap alternatif properti yang ditentukan

Gambar 1. Diagram Penelitian

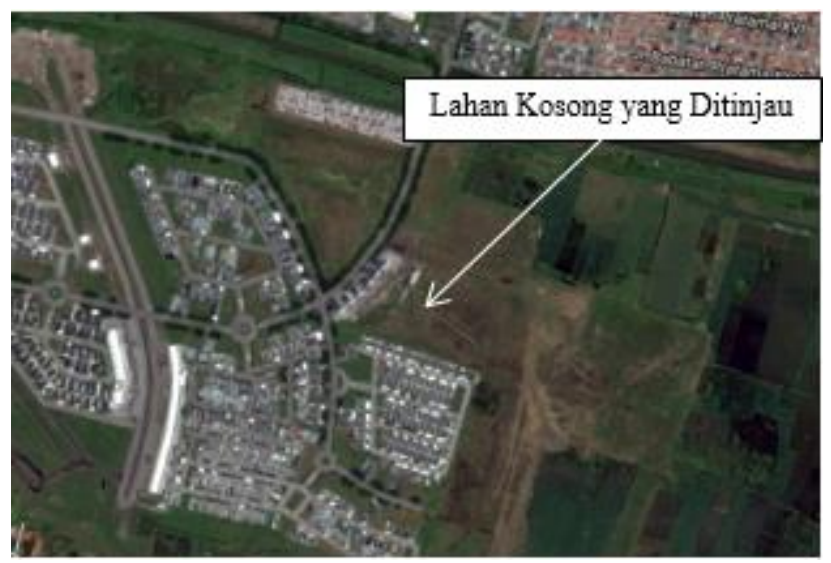

Gambar 2. Lokasi Objek Penelitian

Proses yang dilakukan dalam penelitian ini adalah sebagai berikut: 


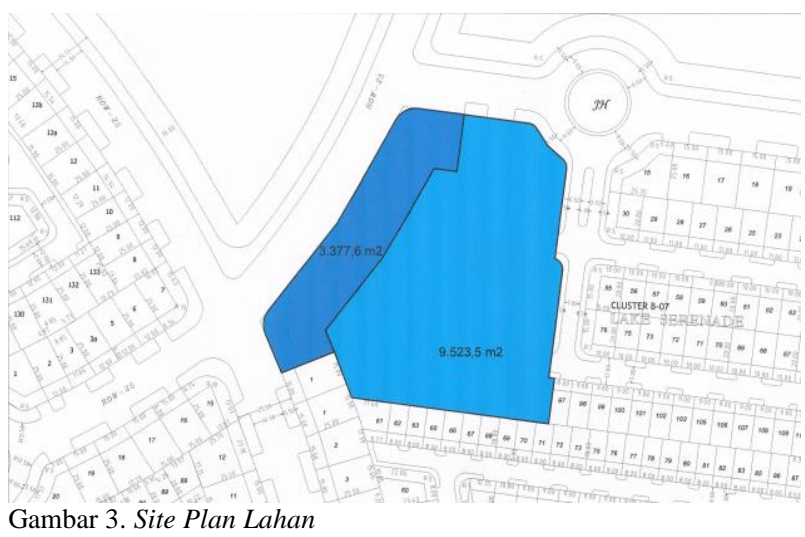

\section{ANALISIS DAN HASIL}

Pada bab ini akan dibahas tentang hasil penelitian pengunaan properti yang menghasilkan nilai lahan tertinggi.

\section{A. Pemilihan Alternatif}

Pemilihan alternatif dilakukan dengan cara penyebaran kuisioner. Kuisioner disebarkan ke para stakeholer untuk mendapatkan alternatif awal. Dari alternatif awal tersebut dilakukan seleksi alternatif dengan menentukan urutan prioritas oleh pihak owner dan diambil 3 urutan teratas untuk dianalisis HBU. Alternatif properti yang akan dianalisis adalah apartemen, mix - use building, dan perumahan.

\section{B. Aspek legal}

Aspek legal merupakan syarat pertama yang harus dilakukan dalam menganalisis Highest and Best Used (HBU). Analisis aspek legal ditentukan untuk mengidentifikasi batasan yang ditentukan secara hukum. Namun perlu diingat bahwa peraturan pemerintah bisa berubah di masa depan sehingga perlu diidentifikasi kumungkinnya.

Aspek legal pada analisis HBU ini mengacu pada Peraturan Walikota Surabaya No. 57 Tahun 2015 tentang Pedoman Teknis Pengendalian Pemanfaatan Ruang dalam Rangka Pendirian Bangunan di Kota Surabaya [10] dan Surat Keterengan Rencana Kota (SKRK) No. 653.5739/426.6.2/2015 [11].

Persyaratan peraturan bangunan untuk alternatif perumahan yaitu :

1. Koefisien Dasar Bangunan : 70\% (untuk kapling $>200 \mathrm{~m}^{2}$ ) $80 \%$ (untuk kapling $<200 \mathrm{~m}^{2}$ )

2. Koefisien Lantai Bangunan : 1,8 poin atau $180 \%$

3. Tinggi Bangunan : 3 lantai

4. $\mathrm{KDH}: 10 \%$

5. GSB : $5 \mathrm{~m}$ depan

0 untuk bagian samping dan belakang

Persyaratan peraturan bangunan untuk alternatif apartemen yaitu :

1. Koefisien Dasar Bangunan : $50 \%$

2. Koefisien Lantai Bangunan : 6 poin atau $600 \%$

3. Tinggi Bangunan $\quad: 70 \mathrm{~m}$

4. $\mathrm{KDH} \quad: 10 \%$

5. GSB

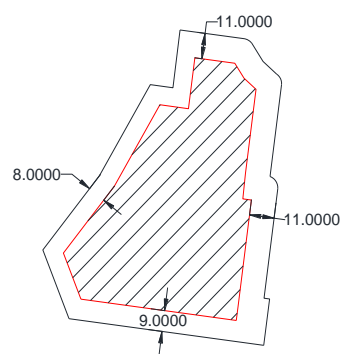

Gambar 4. Garis Sempadan Bangunan Apartemen

Persyaratan peraturan bangunan untuk alternatif apartemen yaitu :

1. Koefisien Dasar Bangunan : $50 \%$

2. Koefisien Lantai Bangunan : 200\% (untuk pertokoan)

$300 \%$ (untuk apartemen)

3. Tinggi Bangunan $\quad: 70 \mathrm{~m}$

4. $\mathrm{KDH}: 10 \%$

5. GSB

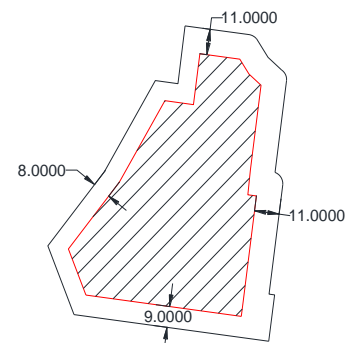

Gambar 5. Garis Sempadan Bangunan Mix Use Building

\section{Aspek Fisik}

Dalam analisis aspek fisik terdapat beberapa kriteria yang meliputi lokasi lahan, ukuran dan bentuk lahan, aksesbilitas ke lokasi dan utilitas. Pada aspek fisik akan didapatkan desain awal masing - masing alternatif.

1. Analisis Lokasi Lahan

Lahan kosong ini berada di J1. Royal Residence B007 02-10 kelurahan Sumur Welut, kecamatan Lakarsantri, Surabaya. Disekitar lahan merupakan daerah perumahan. Didalam perumahan terdapat banyak fasilitas, seperti pusat perbelanjaan. Disekitar area lahan juga terdapat banyak perumahan - perumahan lain, hotel, dan juga area komersial seperti tempat makan, pertokoan, perkantoran, dan juga mall. Selain itu juga mulai banyak terlihat pengembangan properti residensial berupa apartemen.

2. Luas dan Bentuk Lahan

Lahan memiliki luas 9523,5 $\mathrm{m}^{2}$. Bentuk dari lahan ini kurang beraturan di bagian kanan dan depan.

3. Utilitas

Utilitas utama antara lain ketersedian air, listrik, dan saran komunikasi. Kesemua utilitas utama tersebut telah terpenuhi pada lahan penelitian.

4. Analisis aksesibilitas

Lahan ini merupakan lahan di perumahan yang memiliki jalan yang bagus dan lebar. Namun akses menuju perumahan masih kurang baik karenan sering terjadi kepadatan.

5. Desain Alternatif Awal

Setelah ditinjau secara legal, kemudian pada analisis aspek fisik ditentukan desain alternatifnya. Desain alternatif menentukan kapasitas setiap alternatif, mulai dari luas lantai dasar, luas bangunan, tinggi bangunan, dan luas neto bangunan. 


\section{Aspek Finansial}

Tahap selanjutnya setelah dilakukan analisis aspek legal dan aspek fisik adalah analisis aspek finansial. Analisis finansial meliputi biaya investasi, pendapatan, pengeluaran, dan arus kas terdiskon.

1. Perencanaan Biaya Investasi

Dalam perencanaan biaya investasi terdiri dari biaya biaya bangunan dan biaya tanah serta biaya perijinan yang berupa biaya replanning master plan perumahan. Biaya investasi masing -masing alternatif bisa diliat pada Tabel2.

Tabel 2.

Biaya Investasi

\begin{tabular}{ccc}
\hline \hline Jenis Alternatif & \multicolumn{3}{c}{ Biaya Investasi } \\
\hline Perumahan & $\mathrm{Rp}$ & 155.732 .096 .650 \\
Apartemen & $\mathrm{Rp}$ & 722.715 .932 .825 \\
Mix - Use Building 1 & $\mathrm{Rp}$ & 483.071 .419 .478 \\
Mix - Use Building 2 & $\mathrm{Rp}$ & 402.059 .263 .225 \\
Mix - Use Building 3 & $\mathrm{Rp}$ & 327.912 .629 .259 \\
\hline \hline Sumber: Hasil Perhitungan & &
\end{tabular}

\section{Perencanaan Pendapatan}

Perencanaan pendapatan untuk alternatif bangunan berasal dari penjualan atau penyewaan, service charge dan pendapatan parkir.

\section{Perencanaan Pengeluaran}

Perencanaan pengeluaran untuk masing-masing jenis alternatif terdiri dari biaya operasional dan biaya pemeliharan. Biaya operasional terdiri dari biaya karena penggunaan listrik, penggunaan air, dan gaji pegawai.

\section{Analisis Arus Kas}

Analisis arus kas dilakukan dengan metode NPV (Net Present Value) yang dilakukan dengan cara mengurangi pendapatan dengan pengeluaran tiap tahun selama masa investasi sehingga didapatkan aliran kas bersih. Arus kas bersih kemudian disesuaikan dengan faktor terdiskon tingkat pengembalian yang diharapkan. Investasi yang layak ditujukkan dengan nilai NPV positif, sebaliknya investasi yang tidak layak memiliki nilai NPV negatif. Hasil kelayakan finansal dapat dilihat pada Tabel 3.

Tabel 3.

Kelayakan Finansial

\begin{tabular}{|l|c|c|c|c|c|}
\hline \multirow{2}{*}{ Uraian } & \multicolumn{5}{|c|}{ Alternatif } \\
\cline { 2 - 7 } & Apartemen (Rp) & Mix-Use 1 (Rp) & Mix-Use 2 (Rp) & Mix-Use 3 (Rp) & Perumahan (Rp) \\
\hline In vestasi & $(722.715 .932 .825)$ & $(483.071 .419 .478)$ & $(402.059 .263 .225)$ & $(327.912 .629 .259)$ & $(155.732 .096 .650)$ \\
\hline Pendapatan & 288.073 .842 .190 & 214.162 .063 .731 & 214.162 .063 .731 & 206.749 .434 .090 & 147.227 .300 .000 \\
\hline Pengeluaran & $(38.298 .326 .399)$ & $(35.132 .339 .298)$ & $(41.522 .504 .811)$ & $(45.796 .191 .491)$ & $(135.807 .906)$ \\
\hline Ierminal & 490.894 .226 .081 & 333.528 .524 .235 & 287.661 .669 .751 & 256.936 .836 .699 & \\
\hline Value & 17.953 .809 .048 & 29.486 .829 .189 & 50.829 .335 .804 & 85.035 .696 .946 & $(28.849 .386 .990)$ \\
\hline NPV & Layak & Layak & Layak & Layak & Tidak Layak \\
\hline Pengujian & \multicolumn{5}{|c|}{} \\
\hline
\end{tabular}

Sumber: Hasil Perhitungan

Analisis aspek finansial juga dilakukan dengan memtode IRR. Alternatif yang layak secara finansial ditunjukkan dengan nilai IRR lebih besar dari nilai MARR sebesar 9,24\%. Perhitungan IRR dilakukan dengan rumus :

$$
N P V=\sum_{n=0}^{n} \frac{C F}{(1+R)^{n}}=0
$$

Dari hasil perhitungan IRR didapatkan alternatif yang layak dengan IRR lebih besar dari MARR adalah alternatif apartemen, mix-use building 1, mix-use building 2, dan mixuse building 3 . Sedangkan alternatif yang tidak layak dengan nilai IRR lebih kecil dari MARR adalah alternatif perumahan.

\section{E. Produktivitas Maksimum}

Alternatif-alternatif yang telah lulus pengujian aspek legal, fisik, dan finansial akan dicari nilai lahannya melalui uji produktivitas maksimum. Hasil perhitungan produktivitas maksimum dapat dilihat pada Tabel 6 .

Tabel 6.

Produktivitas Maksimum

\begin{tabular}{|l|c|c|c|c|}
\hline \multicolumn{1}{|c|}{ Uraian } & Apartemen & Mix - Use Building 1 & Mix - Use Building 2 & Mix - Use Building 3 \\
\hline Nilai Properti & 834.215 .150 .071 & 566.791 .241 .605 & 488.846 .089 .953 & 436.632 .965 .714 \\
\hline Nilai Investasi & $(722.715 .932 .825)$ & $(483.071 .419 .478)$ & $(402.059 .263 .225)$ & $(327.912 .629 .259)$ \\
\hline Biaya Tanah & 98.535 .789 .513 & 98.535 .789 .513 & 98.535 .789 .513 & 98.535 .789 .513 \\
\hline Nilai Bangunan & $(624.180 .143 .312)$ & $(384.535 .629 .965)$ & $(303.523 .473 .712)$ & $(229.376 .839 .746)$ \\
\hline Nilai Lahan & 210.035 .006 .759 & 182.255 .611 .640 & 185.322 .616 .241 & 207.256 .125 .968 \\
\hline Nilai Lahan /m & 22.054 .392 & 19.137 .461 & 19.459 .507 & 21.762 .601 \\
\hline Nilai Tanah Awal & 10.346 .594 & 10.346 .594 & 10.346 .594 & 10.346 .594 \\
\hline Produktivitas & $113 \%$ & $85 \%$ & $88 \%$ & $110 \%$ \\
\hline
\end{tabular}

Sumber: Hasil Perhitungan

Hasil perhitungan produktivitas maksimum, dengan pengembangan apartemen akan didapatkan penambahan nilai lahan dari nilai awal sebesar Rp. $11.707 .798 / \mathrm{m}^{2}$ dalam arti pemanfaatan lahan untuk apartemen akan memberikan produktivitas lahan sebesar $113 \%$, dengan pengembangan mix - use building 1 akan didapatkan penambahan nilai lahan dari nilai awal sebesar Rp. $8.790 .867 / \mathrm{m}^{2}$ dalam arti pemanfaatan lahan untuk apartemen akan memberikan produktivitas lahan sebesar $85 \%$, dengan pengembangan mix - use building 2 akan didapatkan penambahan nilai lahan dari nilai awal sebesar Rp. $9.112 .913 / \mathrm{m}^{2}$ dalam arti pemanfaatan lahan untuk apartemen akan memberikan produktivitas lahan sebesar $88 \%$, dan dengan pengembangan mix - use building 3 akan didapatkan penambahan nilai lahan dari nilai awal sebesar Rp. 11.416.606/ $\mathrm{m}^{2}$ dalam arti pemanfaatan lahan untuk apartemen akan memberikan produktivitas lahan sebesar $110 \%$. Sehingga, alternatif penggunaan tertinggi dan terbaik untuk lahan penelitian adalah alternatif penggunaan apartemen.

\section{KESIMPULAN}

Penelitian bertujuan untuk menentukan penggunan tertinggi dan terbaik dari lahan di kawasan perumahan Royal Residence. Dari hasil analisis HBU, didapatkan dengan pengembangan apartemen nilai lahan akan mengalami penambahan dari nilai awal sebesar Rp. 11.707.798/m2 dalam arti pemanfaatan lahan untuk apartemen akan memberikan produktivitas lahan sebesar $113 \%$. Jadi, dapat disimpulkan penggunaan tertinggi dan terbaik untuk lahan penelitihan adalah alternatif pengembangan apartemen.

\section{DAFTAR PUSTAKA}

[1] Suprapno. 2010. Pemahaman Sederhana Konsep Highest and Best Uses

<https://www.djkn.kemenkeu.go.id/artikel/detail/pemahamansederhana-konsep-highest-and-best-uses-analysis >

[2] Rasyid, T.D.A. Utomo C., 2013, Analisis Higest and Best Use (HBU) pada Lahan Bekas SPBU Biliton Surabaya. Jurnal Teknik POMITS. Volume 2, Nomor 2, ISSN : 2337-3539. Surabaya.

[3] Akmaluddin. dan Utomo, C. 2013, Analisis Highest and Best Use (HBU) pada Lahan Jl. Gubeng Raya No. 54 Surabaya. Jurnal Teknik POMITS. Volume 2, Nomor 1, ISSN : 2337-3539. Surabaya.

[4] Indrakusuma, R dan Utomo, C. 2014. Analisis Penggunaan Lahan Kosong Jalan Nias Surabaya dengan Metode Highest and Best Used. Institut Teknologi Sepuluh Nopember. Jurusan Teknik Sipil. Surabaya.

[4] Mubayyinah, M dan Utomo, C. 2012. Analisis Highest and Best Use (HBU) Lahan "X" untuk Properti Komersial. Jurnal Teknik ITS Vol. 
1, No. 1, hal. D16-D19.Akmaluddin dan Utomo, C. 2013.Analisis Highest And Best Used Jl. Raya Gubeng No. 54 Surabaya. Jurnal Jurusan Teknik Sipil ITS Vol. 2 No. 1 : 2301-9271 C6-C10.

[5] Anggarwati, B dan Utomo, C. 2013. Analisis Penggunaan Lahan Kawasan Komersial Perumahan Citra Raya Surabaya dengan Metode Highest and Best Use. Surabaya: Jurnal Teknik ITS 2 No.2, D39D41.

[6] Faradiany, F.V. dan Utomo, C. 2014. Analisis Highest and Best Use pada Lahan Kosong di Jemur Gayungan II Surabaya. Surabaya : Jurnal Teknik ITS 3 (2), C61-63.

[7] Utami, N.P.K. dan Utomo, C. 2015. Analisis Highest adn Best Use pada Lahan Kosong di Kawasan Wisata Ubud. Surabaya: Jurnal Teknik ITS Vol. 4, No. 1, C41-C44

[8] Aziz, C.N. dan Utomo, C. 2015. Analisis Highest ad Best Use pada Lahan Gedung Serbaguna Purnama di Jl. R.A. Kartini Bangkalan. Surabaya: Jurnal Teknik ITS Vol. 4, No. 1, D51-D53.

[9] Mubayyinah, M dan Utomo, C. 2012. Analisis Highest and Best Use (HBU) Lahan "X" untuk Properti Komersial. Jurnal Teknik ITS Vol. 1, No. 1, hal. D16-D19.

[10] Pemerintah Kota Surabaya. 2015. Peraturan Walikota Surabaya No. 57 Tahun 2015. Tentang Pedoman Teknis Pengendalian Pemanfaatan Ruang dalam Rangka Pendirian Bangunan di Kota Surabaya. Surabaya.

[11] Surat Keterangan Rencana Kota (SKRK) nomor 653/5739/436.6.2/2015. 